\title{
A MEMOIR OF JOHN V. MURRA
}

\author{
Judith Willis ${ }^{1}$
}

John Murra entered my life when, as a newly hired professor of anthropology at Cornell University he was appointed as field representative for the department, in charge of managing the selection of the year's new crop of graduate students. I had already functioned as the secretary to the previous holder of that position, and he had expressed deep regret and dire predication as to the fate that awaited me as office support for the flamboyant, unpredictable and irrascable John Murra. (I believe "barbarian" was the word he used).

Upon Murra's initial appearance in his new official capacity and after a brief banter between us regarding our new responsibilities, we sized each other up and simultaneously it dawned on us that this was actually going to be fun. And so it was.

John and I embarked upon a kind of mutual aid, admiration and protection society.

I was a great audience for tales of his work in the Andes as well as anecdotes and stories about the rich treasure trove of people and experiences from Romania, the Spanish Civil War, the McCarthy era, Vassar, Puerto Rico, and so on. He, on the other hand, was genuinely curious about and interested in my strange (to him) animal-oriented life, rescued dogs and cats, ornithology classes, moonlighting as a pet sitter, horses and riding lessons.

He was also grateful for my organizational abilities and would often say (in total disbelief) that with all the papers regarding grad. student applicants coming into our office, "she never lost anything!". This was another bond we forged. John had many skills, but neatness was not among them. A regular ritual of our working (and subsequent personal relationship) consisted of John's burying something (papers, keys, tickets, credit cards) and me exploring the geological, archaeological layers of the surfaces, excavating and patting down the piles and unsticking the marmalade to retrieve the lost whatever. He was always bemused and touchingly grateful for whatever I could do to keep things reasonably organized.
Because John was a lifelong insomniac, another strange but helpful service I could offer was protecting him from intrusion when he dropped down his foam mattress from behind the office door to steal a catnap. "I'm sorry, Prof. Murra is unavailable right now". This was one of the many things John taught me, and I now have a similar emergency sleep system in my office.

Each year the field representative headed up a faculty committee to evaluate the 50 or so grad. student applicants for Cornell's Anthropology Dept. and to select the 20 or so who would be admitted. Transcripts, GRE scores, letters of reference and essays on "why I want to be an anthropology graduate student at Cornell University" came pouring in daily. I collected and organized them, and John and I read each new addition to the file, gradually forming a picture of who each student was. John (because of his own background) had a bias toward students with some real-world experience -not just high GRE scores and dazzling academic records. The latter he referred to as "computer candidates" -meaning even a computer could pick them out.

He was looking for the applicant with a clear vision of what they wanted to pursue and some practical idea of how to do it. Students who brought some diverse real-life experience were to him the hopeful ones-a woman who grew up on her family's working apple orchard on an island off the Washington coast, the daughter of Polish immigrants from working-class Chicago, a former priest who had taken a vow of silence.

Based on their backgrounds it was then John's job to assemble the committee of faculty members representing the various specialties and present the piles of applicants, giving an overview of each, and perhaps nudging the particularly interesting ones closer to the top. The applicants were ranked by each of the committee members and little by little the next class of students was selected.

The following semester we got to meet and get to know them "for real". My job became that 
of behavioral interpreter for those students seeking an audience with the formidable Prof. Murra. What kind of a mood was he in today? How should I address him? What did he mean by calling me a monolingual cripple? I also tried to warn intimidated students who were literally backing out of my office followed by the still-talking John Murra that they were about to crash into the structural support pole just outside the door.

I spent considerable time trying to reassure students that they shouldn't take his dramatic and sometimes dire pronouncements too personally, that it was just his way of making them take things seriously and expressing the passion he felt about anthropological issues. On the other hand, I also had to counsel John that sometimes he scared the daylights out of the more fragile souls. I think he didn't really understand the impact he had on people.

I made many dear friends among the graduate students I met during this era, several of whom I have remained in contact with over the past 30 years. And John Murra and I were destined to remain affectionately, almost familialy attached throughout the rest of his life.

Because John had no very close friends of family in the Ithaca area, he came to depend upon me to arrange his many travels and help maintain his household in his absence.

His lack of skill with electronics and mechanical equipment was notorious, so much so that he actually thought that I, (a self-described mechanical nincompoop) was a genius in these areas. There were many late-night calls to discipline recalcitrant TV's and copiers. I remember one incident when John received a new Bose radio as a gift when I was requested to explain at some length the on/off function. We used a lot of white-out to mark "the only button that should be touched". John took this lack of ability as a trade-off for the more exotic gifts he did have. He always told me that, while he couldn't use a remote control, he could read, speak and write in five languages, after all. Different people are good and different things. He was a champion of diversity long before it was fashionable.

John also had very personal and well-developed taste in home decorating, and wanted his house on Dryden Rd. to reflect his background and interests. Freda Wolf helped him install the rose-colored cork wall from Spain in his living room, which reminded him of his time in the Spanish Civil War. Freda's brother Marty painted a quipu scene from Waman Puma in the dining room.

I helped him have curtains made out of fabric he brought home from Cuzco.

My specialty was finding people who could do the "arts \& crafts" decorative things, make a garden for his beloved peonies, or fix things around the house. Helping John arrange his travels was another major and colorful task. It offered me many opportunities to "find things" and put the pieces together, which seems to satisfy something in me: finding the lost hotel (he could describe it but forgot the name), looking for the manuscript that must go with him, arranging to have left-behind items sent back home. And so it was a symbiotic relationship. Meanwhile I got to vicariously follow John's travel adventures without leaving home.

In (1991?) John took a bad tumble down the staircase at Dryden Rd. while trying to catch the mailman to give him an important dispatch. As anyone close to him knew, "The Mail" had huge importance to John. It connected him to his far-flung colleagues all over the world. He would never just drop a letter into any old mailbox. He would walk all the way down to the mother- ship Post Office to make sure his package or letter got off as soon as possible.

But the fall on the stairs had serious consequences. There was blood that collected on his brain which required an operation and follow-up physical therapy. Upon his return to Dryden Rd., there was great concern over John's safety negotiating those stairs. He took to making fun of it by wearing a bike helmet, which he kept on the post at the top of the stairs, but it was also a reminder of the danger.

Over the next few years all of John's friends weighed in on how to handle the problem of creating a secure household and getting the assistance he would need without invading his privacy. Having other people in the house was the most desirable option, but the only people John really liked having as tenants was Luis and Morato. They had the little apartment in the basement, which was probably somewhat difficult for them, and even though John liked them enormously, I'm sure he was not always easy to live with.

After several years during which John's walking ability deteriorated, I convinced him to try living in an apartment at Longview, (an elder housing complex in the area,) while keeping the house on Dryden Rd., where he could go anytime 
he wanted. John's wonderful friends the Rasnakes came to help him move in, heroically dragging in furniture and going with him to pick out some new things. But while the facility itself was quite pleasant, John hated the "American" food and the folksy invasiveness of the place. It was time for me to figure out a better alternative. We looked at several other rental options to get all the necessities on one floor and in close proximity. We discovered Cayuga Apartments, a graceful old building at the edge of downtown Ithaca with an ancient but still elegant old elevator.

I think John liked it because it reminded him of his time in New York City.

I arranged for another move. Glynis Hart came to help get things together for this one. This was a smaller apartment, but John could walk all over downtown by himself. The farmers' market set up right across the street on Tuesdays, and he could visit the natural food store and the deli around the corner.

John's vision was beginning to fail because of incipient glaucoma. He really needed home visitors to help out, but we had to find those special people who John would actually like -meaning smart, not condescending, interesting to talk to, and good listeners. This was not easy! John hated not being independent, so giving him as much leeway to do things himself was crucial. On the other hand, we were always worried about falls and the time he spent alone.

Another apartment opened up in the same building, this one large enough to accommodate someone who could live-in if necessary. Another year, another move! At this point it became clear that the house on Dryden Rd. was never going to be useful. With much sadness, John came to terms with this and sold it. David Block, an old friend of John's who was the curator of Cornell Library's Latin American Studies collection, helped with the herculian task of sorting the Murra books and papers. I will always remember David (who is 6' something) sitting in the Dryden Rd. basement with its very low ceilings, pouring over John's books and papers wearing the bicycle helmet, so that he wouldn't crack his head again when he stood up too fast. The most precious things came to the apartment. John tried to figure out who among his students, colleagues and friends would be the appropriate recipients of specific books, and supervised the mailings of these gifts. He also sent off piles of materials to libraries in Peru, Bolivia, Equador and Chile.

John really liked the new bigger more attractive apartment, and liked having some of his favorite things from the house to familiarize the place. Many of John's old friends came to visit him there, much to his delight. We celebrated at least two of his birthdays there. And it was only two blocks to Dano's, his favorite restaurant in Ithaca, because they served an intriguing mixture of Hungarian, Viennese and eastern European cuisine- his "roots food!"

Eventually, the need for round-the-clock assistance was such that a decision had to be made. Either nursing home care (which I thought would be miserable for him) or a bigger house with enough room upstairs to accommodate at least a couple of people who could do shifts of caring for John -were the choices. So, we made another move a few blocks from the Cayuga Apts.

Here we found several "interesting" and dedicated caregivers who rotated through the days and nights, under the supervision of the professional home-health care visitors. Many of John's old friends came to visit here, also, and were even able to stay at the house. Additionally, my friend Sally VanOrman made available her bed-and-breakfast to a steady stream of John Murra friends and colleagues who would come to town every so often to see him. Usually her house was dedicated to putting up primarily women, but in the case of John's friends, she made an exception. He would have appreciated that.

My experience with John Murra was probably quite different from that of his innumerable academic friends and colleagues. It was a view from backstage and it allowed him to reveal his vulnerabilities -both the endearing and troublesome ones. Peculiar as our connection was, it was a true symbiosis.

It allowed me to see aspects of him that his professional self (which he took so seriously) tended to obscure: his kindness, the ironic and humorous outlook on life (which we shared) and his dignity and fiestinessin dealing with the infirmities of old age. It is notable that, from this up-close vantage point, and even after dealing with the innumerable loose ends of his life over three decades, John Murra continued to inspire both loyalty and affection -a great tribute to his human qualities. 
